\title{
Analysis Of Implementation Green Infrastructure Of Bregas Regional Water Supply System
}

\author{
Anom Guritno ${ }^{1}$, Sudarno Sudarno ${ }^{2}$ \\ ${ }^{1}$ Magister Program of Environmental Science, School of Postgraduate Studies, Diponegoro University, Semarang - Indonesia \\ ${ }^{2}$ Department of Environmental Engineering, Faculty of Engineering, Diponegoro University, Semarang - Indonesia
}

\begin{abstract}
The eco-friendly drinking water supply system (Green WSS) is an important issue in Indonesia's development related to the low implementation of Green WSS in existing water supply building. While the current water supply system development criteria should have more efficient and eco-friendly infrastructure. This study aims to assess the implementation of Green WSS on Bregas Regional Water Supply System. Regional Water Supply System service areas of Bregas include Brebes Regency, Tegal City, and Tegal Regency with total discharge of $650 \mathrm{~L} / \mathrm{sec}$ will be able to serve 52.000 connection house or some 260.000 people. Analysis method that used in this research is scoring analysis of Green WSS indicator and SWOT analysis, data collection obtained by interview, observation, and document study related to planning phase, construction phase, and operational and maintenance phase. According to the results of scoring analysis Green WSS indicator, Bregas Regional Water Supply System has a score of 264 out of 285 (green category) and based on SWOT analysis, it is in quadrant II, meaning the implementation of Green WSS shows the average condition. From those condition have been formulated 13 management strategies of Bregas Regional Water Supply System.
\end{abstract}

Keywords : green water supply system; Bregas water supply system; SWOT analysis

\section{Introduction}

Sustainable development is a mindful and planned effort that combines environmental, social and economic aspects into a development strategy to ensure the integrity of the environment also the safety, abilities, welfare, and quality of life of present and future generations [1]. One of the efforts in realizing sustainable development is by carrying out development on the Drinking Water Field.

This study will review the fulfillment of clean water in Central Java Province and the need for implementation of Green WSS at Regional WSS in Central Java (Case Study Of Bregas Water Supply System). Implementation of Green WSS in Regional WSS covers the application of green open space in the all of water plant building, utilization of renewable energy source (green energy), low carbon and the effort of developing energy-saving and green building in water treatment plant, in its planning stage,construction stage and operational stage.

It is expected that with the implementation of Green WSS on Regional WSS development in Central Java can improve drinking water service followed by significant economic development.

\section{Literature Review}

Drinking Water Supply System hereinafter abbreviated as WSS is a unity of facilities and infrastructure of drinking water supply.

WSS type consists of WSS pipeline network and WSS not pipeline network. WSS pipeline networks include raw water units, production units, distribution units, and service units, while WSS not a pipeline network consisting of shallow wells, pump wells, rainwater catchment basins, water terminals and water catchment buildings.

The implementation of WSS is held to ensure people's right to drinking water, access to drinking water services and fulfill the daily basic needs of drinking water for the community.

The regional system in the implementation of WSS development refers to the second Master Plan namely the WSS Master Plan Development across Districts and/or Cities. The Master Plan is established by the Governor with the support of the Joint Decree of the respective regional head.

In the case of availability of raw water, the Central Government and the Regional Government shall ensure the availability of raw water. Central Government and 
Local Government can do cooperation between regions in the framework of raw water utilization efficiency.

Green WSS is an important issue in development in Indonesia due to the low level of green WSS implementation on existing water supply building. Basically, the application of Green WSS cannot be separated from green construction which is the basic step of indicator to produce green building.

Green building is a concept for 'sustainable building' and has certain conditions, namely location, planning and design system, renovation and operation, which adheres to the principle of energy saving and must have positive impact for environment, economy and social (Ministry of Environment, 2001).

In planning of WSS buildings, green building begins at the planning, development, operation and maintenance operations with pay attention to aspects of protecting, saving, reducing the use of natural resources, maintaining the air quality in the room and pay attention on the occupants health.

In this study, Green WSS is a sustainable movement that aspires to create green building from the planning, construction and operational \& maintenance phase. In order to realize the movement, an assessment indicator is required in each phasing. Determination of indicators at the planning stage, construction phase, and operational \& maintenance stage includes 5 aspects, namely technical aspects, laws and regulations, institutions, social, and finance.

\section{Research Methods}

\subsection{Identification Of Green Water Supply System Indicators}

An indicator is a variable that can be used to evaluate the situation or the possibility of measurement of changes occurring over time. An indicator does not always explain the situation as a whole but often gives only a hint or indication of the overall state as an estimate. Indicators must be simple, timely, measurable, useful, and reliable.

This analysis will discuss the current condition of Bregas Regional Water Supply System with reference to 3 stages of Green Water Supply System indicator covering technical, legal and regulatory, institutional, financial and social aspects. Each indicator consists of several ratings containing credit that has a certain value charge and will be processed to determine the final value. In the selection of issues and indicators that will be used has been conducted site survey based on the real situation to obtain the following indicators:

From Green Water Supply System indicator above, then will be analyzed by means of assessment of each answer on each substance has been determined, namely:

a) score 1-5 if it supports Green WSS (according to rating that have a predetermined value charge)

b) score 0 if it does not supports Green WSS Examples:

If there has a Feasibility Study (FS) document, then it is stated support Green WSS, then by category:

- Complete Feasibility Study, score 5
- Feasibility Study Simple, score 3

- Technical and cost justification, score 1

Based on the considerations, to determine whether a building can be stated to have eco-friendly building criteria, the final result of scoring indicator analysis has a total scoring value of $\geq 75$ of $100 \%$ total.

\subsection{Methods Of Data Collection (Documents, Interview, Survey)}

Data collection techniques implemented include:

a. Observations

Collecting data by conducting direct observation to the object or research location to get a clear picture of the object under study.

b. Interviews

Implemented with in-depth interviews conducted to the parties who are competent and have a fairly good knowledge in formulating strategies in the Water Supply Program in Central Java, especially Bregas.

c. Literature Reviews

The literature study is the activity of collecting various supporting data including study and research reports, scientific publications, laws, maps and other forms of publication related to the research.

\subsection{Methods Of Data Analysis (Indicators Scoring, SWOT Analysis)}

Data analysis methods is an attempt done by grouping data, finding patterns, finding what is important and what is learned and deciding what can be told to others (Bogdan \& Biklen, 1982) ${ }^{[11]}$. In the analysis phase, the data obtained will be processed in accordance with the grouping.

Tabel 2. Data Analysis Method

\begin{tabular}{|c|c|c|}
\hline DATA INPUTS & PROCESSES & RESULTS \\
\hline $\begin{array}{l}\text { Describe and } \\
\text { analyze the } \\
\text { implementation of } \\
\text { Green WSS on } \\
\text { Bregas Regional } \\
\text { WSS }\end{array}$ & $\begin{array}{l}\text { 1. Assessing the } \\
\text { implementation } \\
\text { of Green WSS } \\
\text { on Bregas } \\
\text { Regional WSS } \\
\text { technology } \\
\text { 2. Assessing the } \\
\text { impact of Green } \\
\text { WSS } \\
\text { implementation } \\
\text { on technical, } \\
\text { regulatory/legal, } \\
\text { institutional, } \\
\text { financial and } \\
\text { social aspects }\end{array}$ & $\begin{array}{l}\text { Obtained the } \\
\text { description of Green } \\
\text { WSS } \\
\text { implementation } \\
\text { analysis on Bregas } \\
\text { Regional WSS } \\
\text { covering } 5 \text { aspects. } \\
\text { Obtained the Green } \\
\text { WSS indicator } \\
\text { scores on the Bregas } \\
\text { Regional WSS }\end{array}$ \\
\hline
\end{tabular}

Source : Processed data, 2018

SWOT analysis is described descriptively from the observation data and manager interviews analyzed based on Green WSS criteria. Qualitatively, SWOT analysis is used in analyzing internal and external factors to formulate existing strengths and weaknesses, as well as 
the opportunities and threats that must be faced. Quantitative analysis in SWOT is done by giving weight and rating so as to produce SWOT matrix (David, 2009) ${ }^{[12]}$.

\section{Result And Discussion}

\subsection{Indicators Skoring of Green Water Supply System}

From the results of the analysis that has been implemented, the scoring of indicators obtained in each aspect that has been determined. For more details can be seen in the table 3.

From the results of the above analysis, the total value of 5 aspects of Green WSS indicator is 264 out of 285 or 93\% indicating that Bregas Regional Water Supply System Infrastructure into the Green category.

Classification of Green WSS Indicators Value

$\begin{array}{lll}0-56 & (0-20 \%) & \text { : Black } \\ 57-113 & (20-40 \%) & \text { : Red } \\ 114-170 & (40-60 \%) & : \text { Blue } \\ 171-227 & (60-80 \%) & : \text { Yellow } \\ 228-285 & (80-100 \%) & \text { : Green }\end{array}$

Tabel 3. Green WSS Scoring Indicator of Bregas Regional Water Supply System

\begin{tabular}{|c|c|c|c|}
\hline No & Stages & Indicators & Scoring \\
\hline & $\begin{array}{l}\text { Technical } \\
\text { Aspects }\end{array}$ & & \\
\hline \multirow[t]{4}{*}{1} & $\begin{array}{l}\text { Planning } \\
\text { Stages }\end{array}$ & $\begin{array}{l}\text { The availability of Water } \\
\text { Supply System Master Plan } \\
\text { (RI-SPAM) }\end{array}$ & 4 \\
\hline & & $\begin{array}{l}\text { The availability of } \\
\text { Feasibility Study }\end{array}$ & 5 \\
\hline & & $\begin{array}{l}\text { The availability of Detailed } \\
\text { Engineering Design (DED) }\end{array}$ & 5 \\
\hline & & $\begin{array}{l}\text { The availability of } \\
\text { Environment Permit } \\
\text { Documents (Amdal/UKL- } \\
\text { UPL) }\end{array}$ & 5 \\
\hline \multirow[t]{7}{*}{2} & $\begin{array}{l}\text { Construction } \\
\text { Stages }\end{array}$ & $\begin{array}{l}\text { The suitability of land use in } \\
\text { the field, is it in accordance } \\
\text { with the planning? }\end{array}$ & 5 \\
\hline & & $\begin{array}{l}\text { The suitability of the system } \\
\text { in the field, is it in } \\
\text { accordance with the } \\
\text { planning? }\end{array}$ & 4 \\
\hline & & $\begin{array}{l}\text { The use of building } \\
\text { materials, harmful to health } \\
\text { and the environment or not? }\end{array}$ & 5 \\
\hline & & Energy use & 3 \\
\hline & & Waste management & 4 \\
\hline & & Environmental damage & 5 \\
\hline & & $\begin{array}{l}\text { Implementation of Health } \\
\text { and Safety Management } \\
\text { System }\end{array}$ & 4 \\
\hline 3 & $\begin{array}{l}\text { Operational } \\
\text { and }\end{array}$ & $\begin{array}{l}\text { Quantity, quality and } \\
\text { continuity of WSS including } \\
\text { water leakage }\end{array}$ & 4 \\
\hline
\end{tabular}

\begin{tabular}{|c|c|c|c|}
\hline & \begin{tabular}{|l|} 
Maintenanc \\
e Stages
\end{tabular} & & \\
\hline & & Energy use & 5 \\
\hline & & Waste management & 5 \\
\hline & & Environmental damage & 5 \\
\hline & & $\begin{array}{l}\text { Implementation of Health } \\
\text { and Safety Management } \\
\text { System } \\
\text { - Standard Operating } \\
\text { Procedure } \\
\text { - Work tools standard }\end{array}$ & 4 \\
\hline & & $\begin{array}{l}\text { Efforts of the managements } \\
\text { parties related to water } \\
\text { conservation }\end{array}$ & 5 \\
\hline & Total & & 77 \\
\hline & $\begin{array}{l}\text { Legal } \\
\text { Aspects }\end{array}$ & & \\
\hline \multirow[t]{3}{*}{1} & $\begin{array}{l}\text { Planning } \\
\text { Stages }\end{array}$ & $\begin{array}{l}\text { Availability of national } \\
\text { regulations on Regional } \\
\text { WSS }\end{array}$ & 5 \\
\hline & & $\begin{array}{l}\text { Availability of Bregas } \\
\text { Regional WSS specific } \\
\text { regulations }\end{array}$ & 5 \\
\hline & & $\begin{array}{l}\text { Availability of direct } \\
\text { institutional regulations }\end{array}$ & 5 \\
\hline \multirow[t]{3}{*}{2} & \begin{tabular}{|l|} 
Construction \\
Stages
\end{tabular} & $\begin{array}{l}\text { Standart Operating } \\
\text { Prosedure (SOP) application }\end{array}$ & 5 \\
\hline & & $\begin{array}{l}\text { Suitability with technical } \\
\text { specification }\end{array}$ & 5 \\
\hline & & $\begin{array}{l}\text { Occupational Health and } \\
\text { Safety application }\end{array}$ & 5 \\
\hline 3 & $\begin{array}{l}\text { Operational } \\
\text { and } \\
\text { Maintenance } \\
\text { Stages }\end{array}$ & $\begin{array}{l}\text { Availability of Standard } \\
\text { Operational Procedures } \\
\text { document }\end{array}$ & 5 \\
\hline & & $\begin{array}{l}\text { Avaibilty of Occupational } \\
\text { Health and Safety document }\end{array}$ & 3 \\
\hline & Total & & 38 \\
\hline & \begin{tabular}{|l|} 
Institutional \\
Aspects
\end{tabular} & & \\
\hline & $\begin{array}{l}\text { Planning } \\
\text { Stages }\end{array}$ & $\begin{array}{l}\text { Support from the } \\
\text { government }\end{array}$ & 5 \\
\hline & & $\begin{array}{l}\text { The existence of institutional } \\
\text { who manages the WSS }\end{array}$ & 5 \\
\hline & & $\begin{array}{l}\text { The existence of institutional } \\
\text { who responsibilities the } \\
\text { WSS }\end{array}$ & 5 \\
\hline & & $\begin{array}{l}\text { The existence of official } \\
\text { supervision institutional }\end{array}$ & 5 \\
\hline & \begin{tabular}{|l|} 
Construction \\
Stages
\end{tabular} & Contractor criteria & 4 \\
\hline & & $\begin{array}{l}\text { The existence of field } \\
\text { supervisor }\end{array}$ & 4 \\
\hline & & $\begin{array}{l}\text { Coordination with planning } \\
\text { construction }\end{array}$ & 5 \\
\hline & & $\begin{array}{l}\text { Involvement of the } \\
\text { managing candidate }\end{array}$ & 5 \\
\hline
\end{tabular}




\begin{tabular}{|c|c|c|}
\hline & $\begin{array}{l}\text { Involvement of other } \\
\text { stakeholders }\end{array}$ & 5 \\
\hline \multirow[t]{4}{*}{$\begin{array}{l}\text { Operational } \\
\text { and } \\
\text { Maintenance } \\
\text { Stages } \\
\end{array}$} & $\begin{array}{l}\text { PDAB organization } \\
\text { structure }\end{array}$ & 5 \\
\hline & $\begin{array}{l}\text { Organizational structure of } \\
\text { Bregas Regional WSS }\end{array}$ & 5 \\
\hline & $\begin{array}{l}\text { Bregas Regional WSS } \\
\text { special supervision } \\
\text { institutional }\end{array}$ & 4 \\
\hline & $\begin{array}{l}\text { Stakeholder and community } \\
\text { involvement }\end{array}$ & 5 \\
\hline Total & & 62 \\
\hline \begin{tabular}{|l|} 
Financial \\
Aspects
\end{tabular} & & \\
\hline \multirow[t]{5}{*}{$\begin{array}{l}\text { Planning } \\
\text { Stages }\end{array}$} & $\begin{array}{l}\text { Survey of local unit price or } \\
\text { government price }\end{array}$ & 5 \\
\hline & $\begin{array}{l}\text { Analysis of construction } \\
\text { costs as per the needs of the } \\
\text { field or not }\end{array}$ & 5 \\
\hline & Investment costs & 5 \\
\hline & $\begin{array}{l}\text { Funding costs lighten the } \\
\text { management or not }\end{array}$ & 5 \\
\hline & Financial feasibility & 5 \\
\hline \begin{tabular}{|l|} 
Construction \\
Stages
\end{tabular} & $\begin{array}{l}\text { Suitability with investment } \\
\text { costs in DED }\end{array}$ & 5 \\
\hline \multirow[t]{2}{*}{$\begin{array}{l}\text { Operational } \\
\text { and } \\
\text { Maintenance } \\
\text { Stages }\end{array}$} & Operational cost & 5 \\
\hline & Tariff & 5 \\
\hline Total & & 40 \\
\hline $\begin{array}{l}\text { Social } \\
\text { Aspects }\end{array}$ & & \\
\hline \multirow[t]{3}{*}{$\begin{array}{l}\text { Planning } \\
\text { Stages }\end{array}$} & $\begin{array}{l}\text { Socialization to the } \\
\text { community }\end{array}$ & 5 \\
\hline & Special approach to society & 4 \\
\hline & $\begin{array}{l}\text { Community involvement in } \\
\text { design planning }\end{array}$ & 3 \\
\hline \multirow[t]{5}{*}{$\begin{array}{l}\text { Construction } \\
\text { Stages }\end{array}$} & $\begin{array}{l}\text { Socialization ahead of } \\
\text { construction }\end{array}$ & 5 \\
\hline & $\begin{array}{l}\text { Local people involvement in } \\
\text { construction processes }\end{array}$ & 3 \\
\hline & $\begin{array}{l}\text { Disruption from residents } \\
\text { during construction } \\
\text { progresses }\end{array}$ & 5 \\
\hline & Involvement of CSR & 4 \\
\hline & $\begin{array}{l}\text { Supervision from the } \\
\text { community }\end{array}$ & 5 \\
\hline $\begin{array}{l}\text { Operational } \\
\text { and } \\
\text { Maintenance } \\
\text { Stages }\end{array}$ & $\begin{array}{l}\text { Socialization ahead of } \\
\text { operational activities }\end{array}$ & 3 \\
\hline
\end{tabular}

\begin{tabular}{|l|l|l|c|}
\hline & $\begin{array}{l}\text { Involvement of residents in } \\
\text { operational activities }\end{array}$ & 5 \\
\hline & $\begin{array}{l}\text { Disruption from residents } \\
\text { during operational }\end{array}$ & 5 \\
\hline & Sub Total & & $\mathbf{4 7}$ \\
\hline & Total & & $\mathbf{2 6 4}$ \\
\hline
\end{tabular}

Source :Analyzed, 2018

\subsection{SWOT Analysis}

This matrix function is to measure how big of internal and external factors role in Green WSS Implementation and Bregas Regional WSS. Based on the weight value in internal and external factors are made IFE and EFE matrixs.

Table 8. Matrix of Internal Factors Evaluation (IFE)

\begin{tabular}{|l|c|c|c|}
\hline \multicolumn{1}{|c|}{ Internal Factors } & weight & Rating & Score \\
\hline Strengths & $\mathbf{1}$ & $\mathbf{2}$ & $\mathbf{3}$ \\
\hline $\begin{array}{l}\text { Raw water quality } \\
\text { (Springs) }\end{array}$ & 0,126 & 3,4 & 0,431 \\
\hline $\begin{array}{l}\text { The commitment of Local } \\
\text { Government in realizing } \\
\text { WSS development } \\
\text { program }\end{array}$ & 0,131 & 3,1 & 0,411 \\
\hline $\begin{array}{l}\text { Special Regulations of } \\
\text { WSS Regional }\end{array}$ & 0,126 & 3,4 & 0,431 \\
\hline $\begin{array}{l}\text { The desire from people to } \\
\text { get clean water service }\end{array}$ & 0,121 & 3,1 & 0,379 \\
\hline $\begin{array}{l}\text { The participation from } \\
\text { community in the } \\
\text { implementation of WSS }\end{array}$ & 0,116 & 1,9 & 0,215 \\
\hline Weakness & 0,126 & 3,0 & 0,377 \\
\hline $\begin{array}{l}\text { The cost of investment is } \\
\text { huge }\end{array}$ & 2,9 & 0,359 \\
\hline $\begin{array}{l}\text { Pipeline system / path is } \\
\text { prone to leakage due to } \\
\text { passing fault areas (bad } \\
\text { topography) }\end{array}$ & 0,126 & 3,0 & 0,392 \\
\hline $\begin{array}{l}\text { There are still untapped } \\
\text { water sources }\end{array}$ & 0,131 & $\mathbf{2 , 9 9}$ \\
\hline
\end{tabular}

Source :Analyzed, 2018

Table 9. Matrix of External Factors Evaluation (EFE)

\begin{tabular}{|l|c|c|c|}
\hline \multicolumn{1}{|c|}{ External Factor } & weight & Rating & Score \\
\hline Opportunities & $\mathbf{1}$ & $\mathbf{2}$ & $\mathbf{3}$ \\
\hline $\begin{array}{l}\text { The first Regional Water } \\
\text { Supply System in Central } \\
\text { Java }\end{array}$ & 0,173 & 4,0 & 0,691 \\
\hline $\begin{array}{l}\text { Budget opportunities from } \\
\text { the Central Java } \\
\text { Government }\end{array}$ & 0,142 & 2,9 & 0,406 \\
\hline $\begin{array}{l}\text { Special management } \\
\text { agency }\end{array}$ & 0,154 & 3,6 & 0,551 \\
\hline
\end{tabular}




\begin{tabular}{|l|c|c|c|}
\hline \multicolumn{1}{|c|}{ External Factor } & weight & Rating & Score \\
\hline $\begin{array}{l}\text { The participation of } \\
\text { society }\end{array}$ & $\mathbf{1}$ & $\mathbf{2}$ & $\mathbf{3}$ \\
\hline Threats & 0,123 & 2,4 & 0,300 \\
\hline $\begin{array}{l}\text { Operational and } \\
\text { maintenance technical } \\
\text { more difficult due to } \\
\text { topography factor }\end{array}$ & 0,160 & 3,3 & 0,527 \\
\hline $\begin{array}{l}\text { Operational and } \\
\text { Maintenance costs are big } \\
\text { because the system is easy } \\
\text { to leak }\end{array}$ & 0,167 & 3,3 & 0,548 \\
\hline Social Conflicts & 0,080 & 1,9 & 0,149 \\
\hline \multicolumn{2}{|l|}{} & $\mathbf{3 , 1 7}$ \\
\hline
\end{tabular}

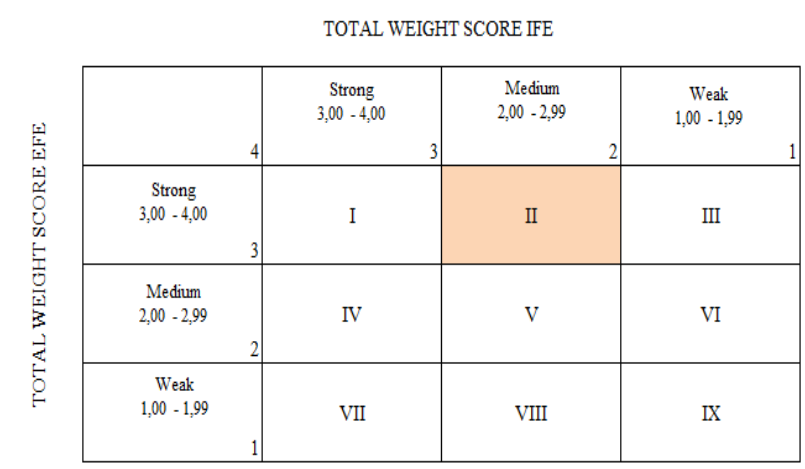

\section{Conclusion}

Based on the data analysis and discussion that has been done in this research obtained the following conclusion:

1. Identification Result Of Green Water Supply System Indicators

According to the results of scoring analysis Green WSS indicator, Bregas Regional Water Supply System has a score of 264 out of 285 (green category).

2. SWOT Analysis

SWOT analysis, it is in quadrant II, meaning the implementation of Green WSS shows the grow and build condition.

\section{Acknoledgements}

Thank you for all the people who have helped to accomplished this research . PDAB Central Java Province as stakeholders of Bregas Regional Water Supply System and all the colleagues.

\section{References}

1. Z. Ding, Z. Fan, V.W.Y. Tam, Y. Bian, S. Li, I.M.C.S. Illankoon, S. Moon, Build\&Env, Green Building Evaluation System Implementation, 133, 32-40 (2018)

2. X. Huo, A.T.W. Yu, Z. Wu, Cl.Prod.J, An Empirical Study of The Variables Affecting Site Planning and Design in Green Buildings, 175, 314-323 (2018)

3. L.O. Ugur, N. Leblebici, Ren\&Sus En Rev, An Examination of The LEED Green Building Certification System in Terms of Construction Costs, 181, 1476-1483 (2018)

4. R. Liu, T. Wei, Y. Zhao, Y. Wang, Chem Eng J, Presentation and perspective of appealing Green Facilities for eco-cyclic water managementI (2017)

5. R.C. Marques, N.F. da Cruz, J. Pires, Env Sci \& Plcy Measuring The Sustainability of Urban Water Services, 54, 142-151 (2015)

6. Carter et al. J. Sci. Food Agric., 79 (11): 1431-1440 (1999)

7. Bogdan, Robert C. and Biklen Kopp Sari, 1982, Qualitative Research for Education: An Introduction to Theory and Methods. Allyn and Bacon, Inc.: Boston London.

8. David, Fred R. 2009. Strategic Management: Manajemen Strategis Konsep. Edisi 12. Jakarta: Salemba Empat.

9. Glavinich, T. E., 2008, Contractor's Guide to Green Building Construction, John Wiley.

10. Kusmayadi \& Sugiarto, E., 2000, Metodologi Penelitian dalam Bidang Kepariwisataan, Jakarta: PT. Gramedia Pustaka Utama.

11. Mukherjr, N \& C. van Wijk, 2003. Sustainability Planning and Monitoring in Community Water Supply and Sanitation : A Guide on the Methodology for Participatory Assessment (MPA) for Community-driven Development Programs, Water and Sanitation Program, World Bank and IRC, The Netherlands

12. Purnomo, Wika D. 2013. Evaluasi Pengelolaan Lanskap Berdasarkan Aspek Tepat Guna Lahan Bagi Bangunan Hijau di P.T. Dahana, Bogor : IPB 